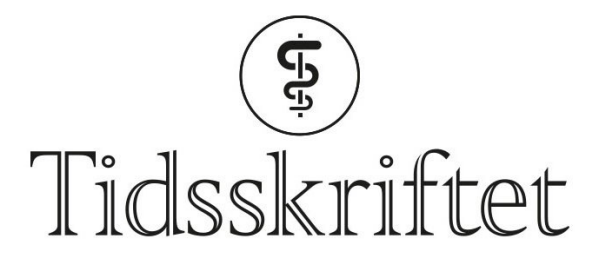

DEN NORSKE LEGEFORENING

\title{
Slik invaderer norovirus tarmen
}

FRA ANDRE TIDSSKRIFTER

RUTH HALSNE

Tidsskriftet

Musestudier viser at tuftceller i tarmslimhinnen er målet for norovirus.

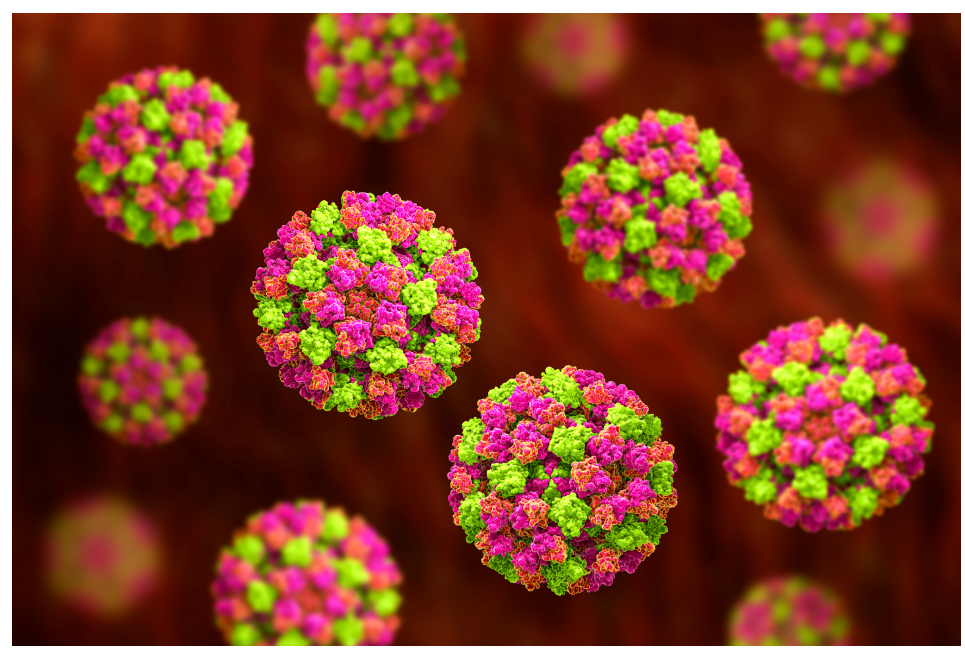

Illustrasjonsfoto: Science Photo Library/NTB scanpix

Norovirusinfeksjon er et globalt helseproblem og forårsaker mer enn 200 ooo dødsfall i året. In vitro-studier tyder på at en reseptor på celleoverflaten, CD3oolf-reseptoren, er nødvendig og tilstrekkelig for norovirusinfeksjon. I en ny studie ble denne kunnskapen brukt til å identifisere hvordan norovirus infiserer in vivo (1).

Mus uten CD3ooIf-reseptor var resistente mot infeksjon. Tarm fra uinfiserte dyr ble undersøkt med fluorescensmikroskopi der CD3ooIf-reseptorer ble påvist i en viss andel av epitelcellene. Disse cellenes distinkte morfologi ga mistanke om at det var såkalte tuftceller, dvs. kjemosensoriske celler i tarmslimhinnen. Dette ble bekreftet ved bruk av spesifikke cellemarkører. I mus med CD3oolf-reseptor fant man en klar samlokalisering av disse cellene og reseptoren.

- Denne studien viser hvilke celler i tarmen som norovirus replikerer i, sier Mette Myrmel, som er førsteamanuensis ved Norges miljø- og biovitenskapelige universitet. Dette er interessant både med tanke på patogenese og på muligheten til å dyrke virus. Per i dag klarer man kun å kultivere menneskets norovirus i organoider fra menneskets tarm, noe som er tungvint. Kultivering er viktig både for å forstå virusets egenskaper og overlevelsesevne utenfor verten. Studien viser dessuten at interleukin (IL)-4 virker direkte på tuftceller og øker virusproduksjonen. Dette kan kanskje utnyttes til etablering av cellelinjer for stabil virusproduksjon, sier Myrmel. 
- Tuftceller produserer IL-25 som starter en type 2-immunreaksjon, med produksjon av IL-4, etter infeksjon med enkelte parasitter. Dette kan tyde på et samspill der en parasittinfeksjon bidrar til en replikasjon av norovirus. Kanskje gjelder dette også andre tarmvirus. Og motsatt: hvilken effekt har norovirusinfeksjon på cellenes produksjon av IL-25 og dermed type 2-immunresponsen mot parasitter? Myrmel understreker at funnene er gjort på mus, og at det er usikkert om studien er overførbar til mennesker.

\section{LITTERATUR:}

1. Wilen CB, Lee S, Hsieh LL et al. Tropism for tuft cells determines immune promotion of norovirus pathogenesis. Science 2018; 36o: 204- 8. [PubMed][CrossRef]

Publisert: 1. oktober 2018. Tidsskr Nor Legeforen. DOI: 10.4045/tidsskr.18.0506

(C) Tidsskrift for Den norske legeforening 2020. Lastet ned fra tidsskriftet.no 